\title{
A Personal Interview with Dr. Jon C. Dalton
}

\author{
Jeanine A. Ward-Roof
}

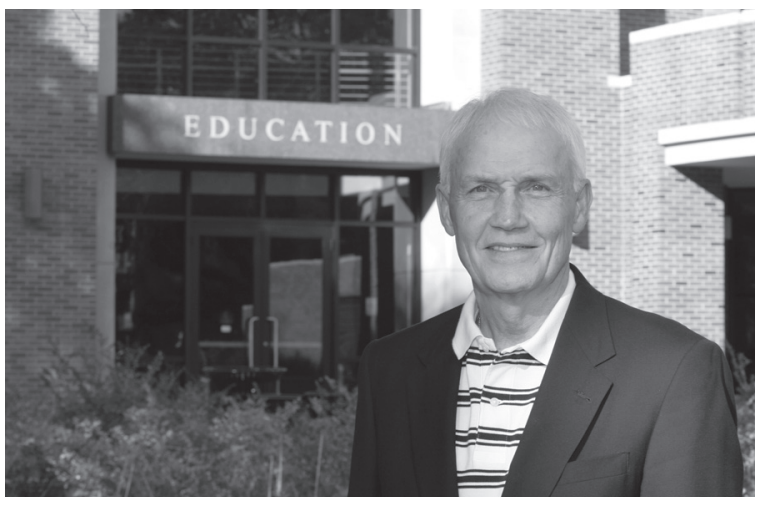

Jon C. Dalton is completing his notable career as an Associate Professor in Florida State University's Department of Educational Leadership and Policy Studies. Many do not know that he began his successful career in the orientation field. His first position in student affairs was at the University of Kentucky where he coordinated a freshman camp.

He worked with 200-300 freshmen who arrived at college a week early to spend time learning about campus life and expectations at a local 4-H camp. Dalton fondly remembers how the camp was "a great way for the new students to bond and return to campus with strong social networks."

He continued to work with the camp program for seven years and spent a total of ten years at University of Kentucky; while there he also completed his doctorate in higher education. Dalton spent the next ten years of his career at Iowa State University where he served as an Associate Dean and Dean of Students while working with Greek life, orientation, and international students. Next he moved to Northern Illinois University as Assistant Vice President for Student Affairs working alongside Margaret Barr; two years later he was appointed Vice President for Student Affairs. In 1989, Dalton and his family moved to Tallahassee, Florida where he served Florida State University for ten years as Vice President for Student Affairs, later transitioning to the faculty where he has spent the past ten years.

Early in his education he discovered he had an interest in the topic of college student moral and spiritual development which developed during three years of social work and study at Yale Divinity School. Dalton noted that he did not know much about the field of student affairs but wanted very much to work in a college or university setting. He found ways in his student affairs work to connect his theological study to student's moral development in college.

His interest in moral development has been a constant throughout his career.

Jeanine A. Ward-Roof (jwardroof@admin.fsu.edu) is the Dean of Students at Florida State University and the Senior Associate Editor of The Journal of College Orientation and Transition. 
At Florida State University, he took the lead in creating the Institute of College Student Values. He later established the Journal College and Character with support from the John Templeton Foundation. Both initiatives had strong connections to moral development and spiritual exploration during the college student experience.

When reflecting upon his career, Dalton stated he always tried to read, write, and teach to stay connected with students and to recharge his own learning and development. He made an intentional choice to teach regularly even when he served as vice president, and he achieved tenure early in his career at Florida State University. In the end this arrangement offered him more security since individuals in most administrative positions work "at the pleasure of the president." Now as a full-time faculty member, he views his role as being responsible for helping to translate and integrate research for practitioners, as they very often do not have time to keep current with the literature. Ultimately he enjoyed being the vice president and found it hard to give up the access to resources when he moved to the faculty; however, he has enjoyed teaching, research, and writing, and even in retirement expects to continue his involvement in these areas.

When asked about changes he saw in the fields of orientation, transition, and retention, Dalton offered the following insights. In the beginning many viewed orientation as a very limited assignment which was coordinated by different people each year. Orientation was often viewed as an introduction to matriculation that lasted for two weeks after which staff and faculty "went back to their regular jobs." Programs consisted of bringing the whole class to campus a few days early before the start of the academic year. New students were processed by the thousands in a gym or cafeteria, listened to a lot of lengthy speeches, and concluded the whole experience in three to five days.

The notion of orientation as the start of the process of assimilation-with time spent introducing students to institutional culture and expectations and facilitating parent interactions - was a tremendous change in the field, but one that was needed. Moreover, as increased numbers of students came to campus with advanced credits, online courses, and dual enrollment, the individual outreach to students became the norm, and expertise in understanding the new specialized aspects of orientation became more important.

Orientation programs grew in scope, and program purposes expanded to include a comprehensive transition process that was an integral facet of campus retention plans. Budgets became more complex, communication more important, and collaboration a new way of thinking as the new orientation model connected all aspects of campus. Today it is often hard to find people who can balance the roles encompassed in orientation positions well. Dalton suggested this new orientation role is valued on campus and requires someone who possesses good organizational skills, as problems typically occur due to poor planning. Additionally, human relations skills are needed as staff must interact with so many diverse people. He stated that successful orientation professionals do not necessarily need a doctorate, but staff members need a good knowledge of the 
academy (including academics) and must be a good representative for the institution. He further cautioned supervisors to not just place young staff who can relate to students in an orientation role but realize the position has evolved and needs more senior and experienced leaders. At the same time, a supervisor must surround the orientation professional with different levels of support and expertise.

Dalton also reflected on the changes in the student population during his career. He reiterated that generally it was important to know the students you serve and that they are different everywhere. Additionally, he noted we have more information on freshmen than we ever had before, including student trends. This information helps us realize how students are changing on macro and micro levels. At the same time he believes that most professionals do not use the data they have on their own campus. Dalton stated that another difference was the characteristics of the current millennial generation. Those students are typically more affluent, have stronger family support, less experience with their own personal development, and limited contact with others who are different than themselves. The current economic crisis is a watershed moment for these students as many have not had to deal with any type of serious adversity; now they are facing circumstances which are shaking their foundations as parents are losing jobs, houses are being foreclosed, and education is becoming more difficult to obtain.

Dalton also stated that although in the last 15 years the 18 - to 25 -year-old student population increased in enrollment by $19-20 \%$, during the next 10 years that number will decrease and enrollment of students 25 years and older will increase. This change would have more impact when coupled with other changes in enrollment patterns such as an increase in part-time students, the number of students who stop-out (intermittently attend), and those who choose to attend community colleges. Dalton predicted these enrollment changes would affect orientation with an increase in demand for more online degrees, evening programs, more accessible services, and the expectation that life experiences should be taken into consideration when creating program contents, format, outcomes, and costs.

Dalton further noted that the current economic trends will affect orientation. He believes that while some may see orientation as a place to cut budgets in difficult financial times, it should always be considered an essential service. Professionals should carefully manage the resources associated with the program and collaborate with other first-year programming staff to ensure needs are met across campus. Additionally, Dalton stated that orientation is a place where campus engagement begins and referred to an article he recently read by Diana Walsh, President of Wellesley College. In the article, Walsh mentioned that budget cuts lead us back to the status quo. He was concerned that if we kept cutting program budgets we would lose the ground we have gained with student engagement, including the work accomplished in orientation.

Dalton also reflected on the impact that rapidly-changing technology has had on our students. He stated there was a great opportunity for orientation professionals to use technology to keep connected with students and help them 
learn about their new community. Dalton compared the combination of changes our students are experiencing and bringing to campus to the turbulent times of the 1960s. He believes the economic crisis will end and we will get back to normal, but the effects of the financial meltdown will be felt for a long time in higher education.

Given Dalton's experience, it was fitting to ask him what he wished he had known as a new professional. He said he wished he were smarter, more mature, and knew what he knows now when he entered the profession. He would have liked for someone to have told him that it was important to pay attention to details, as they can make or break a professional. He would have listened more, as he missed good advice because he thought he already had the answers.

Furthermore, Dalton said he wished someone had talked to him about the importance of balancing his own passion with the realization that others care just as passionately too-they just illustrate their convictions differently. Lastly, Dalton stated he would have liked to know more about budgets, human resources issues, and supervision, as those areas are some of the most difficult to manage and often take the most time and resources.

Dalton ended our interview with the final thought that it did not really matter what area of student affairs staff member worked in; in the end, the students are looking for someone who can advocate for them and ultimately help them learn how to advocate for themselves. He suggested that any professional who wants to be successful should learn how to be an effective student advocate (among other skills needed for his or her position). If professionals are able to accomplish this, the rest of the work will fall into place.

Note: Over his career, Dalton has received many awards and recognitions, from a Rockefeller Foundation Grant for graduate study in 1964 to a Fulbright Grant to attend an International Seminar on Higher Education in Federal Republic of Germany in 1988. In 1997 he was the recipient of the Annuit Coeptis Leadership Award in ACPA, and 1999 brought his recognition as a Fellow by the Society of Values in Higher Education. In 2001 he was awarded the Pillar of the Profession distinction from the NASPA Foundation, and in 2002 he was selected as a Senior Scholar by ACPA. Most recently, he was one of the few professionals recognized with a NASPA Legacy Award at the annual conference in Chicago and received the NASPA 2010 Outstanding Contributions to Literature of Research Award. 